\title{
Travel Philanthropy and Sustainable Development: \\ The Case of the Plymouth-Banjul Challenge
}

\begin{abstract}
Travel philantrophy is an evolving phenomenon. It owes its origins to rising frustrations with conventional aid and traditional philanthropic giving and is seen as development assistance enabling resources to flow directly from the tourism industry into community development and conservation initiatives. Philanthropists have long sought to achieve social transformation and travel philanthropy in all its forms has evolved through the democratization of charity, as a kind of 'doing good' through 'giving back' whilst travelling. This paper evaluates values, practices and impacts of traditional, modern and post-modern philanthropy. Drawing upon evidence emerging from a longitudinal study, which involved the retrospective evaluation of personal diary entries, participant observations and semi-structured interviews about the transcontinental Plymouth-Banjul (car) Challenge (PBC), it exemplifies how an initiative can evolve across all three philanthropic approaches. It further debates critical understandings of the problematic travel philanthropy concept and its role in stimulating sustainable development in subSaharan Africa.
\end{abstract}

Keywords: aid; charity; social entrepreneurship; social justice; sustainability; travel philanthropy; The Gambia. 


\section{INTRODUCTION}

The belief that 'giving' is an unselfish act lies at the heart of philanthropy. It has been suggested that generosity is increasingly en vogue in more developed economies and that high-profile events and campaigns of the last decade, such as the Live Aid concerts and the Make Poverty History campaign, have fostered a culture of philanthropy and charitable gift-giving (Handy, 2007). The notion that one can 'do good' through 'giving back' whilst travelling has seen a concomitant increase in popularity, especially through volunteering (Butcher \& Smith, 2015; Lyons \& Wearing, 2008; McGehee, 2014; Sin, 2010; Wearing, 2001) and has given rise to the wider term of travel philanthropy (Honey, 2011). Philanthropists have sought to achieve social transformation throughout history and travel philanthropy has evolved through the democratization of charity and the growth of international travel and tourism (Sulek, 2010a), especially tourism focused on ameliorating the positions of under-empowered groups. However, questions remain over whether this can be a sustainable form of tourism that translates into effective and equitable development, and whether its expansion has created a 'geography of compassion' (Mostafanezhad, 2013). As a result, De La Mare (2014, p.46) has asked of travel philanthropy "who benefits most - the recipient or the donor?" and questioned whether it simply puts adventure into charity, exacerbating problems such as 'aid dependency' and the poverty cycle. It emerges that considerable ambiguity exists over the benefits and the sustainability of travel philanthropy - for both academics and practitioners.

This paper locates the emergence of travel philanthropy within three broad philanthropic approaches - traditional, modern and post-modern philanthropy, suggesting that, although often associated with the last of these, it traverses each. The paper aims to 
critically investigate its potential role in promoting sustainable development, using the Plymouth-Banjul Challenge (PBC), an annual transcontinental car challenge first staged in 2002, to exemplify an initiative that evolved across all three approaches and culminated as social-justice travel philanthropy. The paper seeks to contribute to the unfolding critical literature and current debate on the morality and efficacy of charity and philanthropy, especially travel philanthropy and approaches such as social-justice tourism (Higgins-Desbiolles, 2008). Given travel philanthropy's tendency towards reactive, shortterm and often incidental charitable contributions and its reliance on individuals who are constantly seeking new experiences, the paper discusses its effectiveness as a sustainable community development solution and draws attention to the complexity of addressing the powerful divisions, which remain between the 'donors' and the recipients of 'aid'.

\section{PHILANTHROPY AND TRAVEL PHILANTHROPY}

There are many non-Western forms of philanthropy, such as those rooted in Islamic cultures (Stephenson, 2014) and Western notions of philanthropy are derived from the Greek philanthropia and carry tonalities of meanings (Adam, 2004). Classic understandings of philanthropy refer to a universal goodwill towards fellow humans; in contrast, contemporary meanings of the term equate it less with imperatives for "pure human goodness' and more with the active promotion and advocacy of social welfare on a global basis (Sulek, 2010a). This definitional shift dates to the growth of industrial capitalism and the increase in charitable organizations during the nineteenth and earlytwentieth centuries, exemplified by the Christian philanthropic activities of the early British travel pioneer Thomas Cook (Brendon, 1991). At this time, understanding of 
philanthropy as a manifestation of universal love for humanity transformed into its current notion of helping humankind through donating money, charitable gift-giving and volunteering (Monroe, 1996; Sulek, 2010a; 2010b).

Reflecting Western rational consciousness and desires to condition human benevolence by materializing it through charity, philanthropy thus changed from “... being a motivator of benevolence to signifying acts of benevolence themselves" (Sulek, 2010a, p.199). In today's Western world, it has become axiomatic to tie philanthropy to charitable actions and to the private giving of time or resources for public good (Frumkin, 2006; Payton, 1988; Salamon, 1992). On this premise, three broad overlapping philanthropic approaches can be distinguished: traditional, modern and post-modern (table 1). In terms of travel philanthropy initiatives, although these are most often associated with post-modern forms of philanthopy, they span all three approaches, and a number have evolved through two or more, including the paternalistic traditional approach, as is the case with the PBC initiatives discussed here. 
Table 1: Locating Philanthropy \& Travel Philanthropy

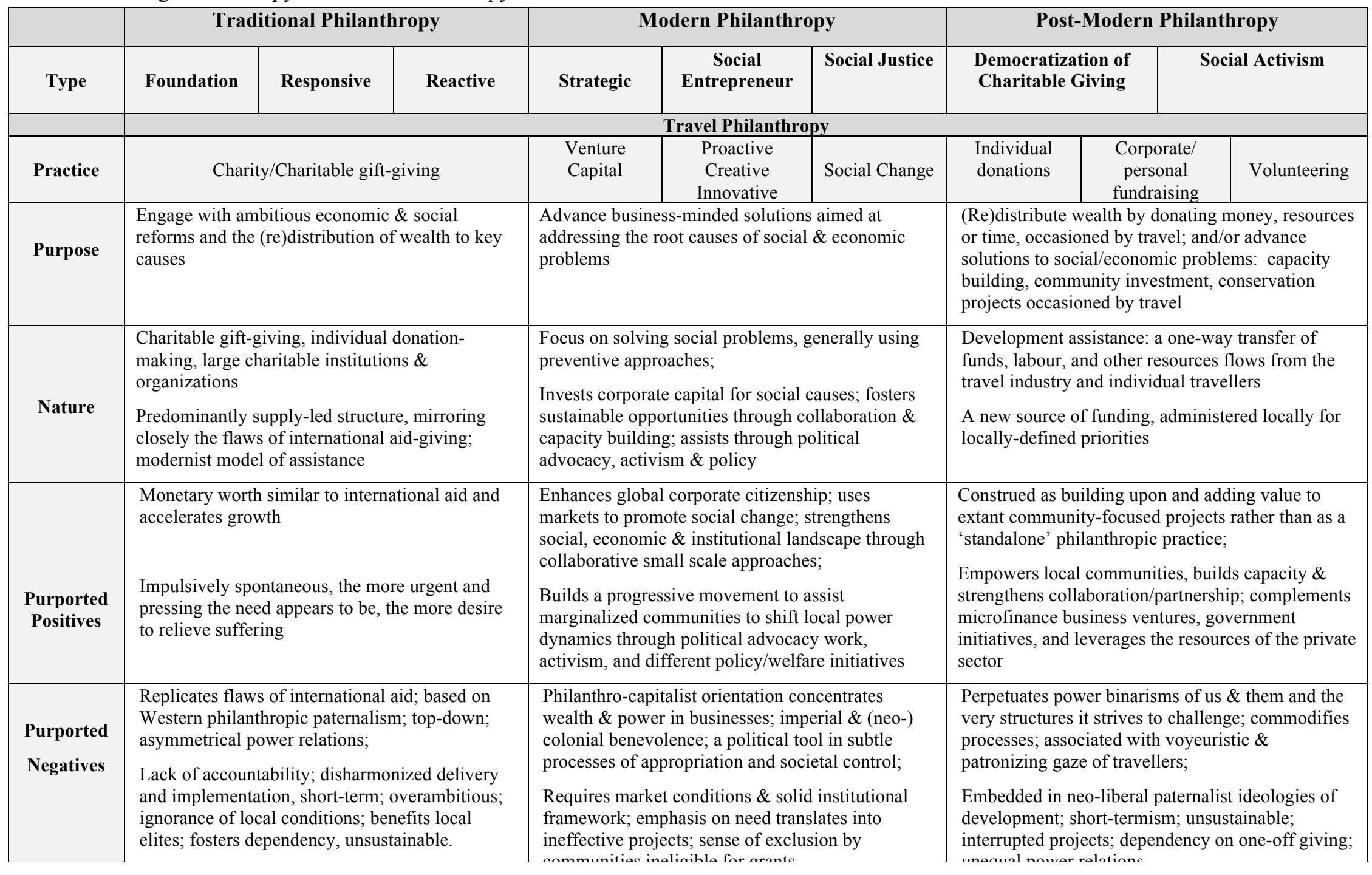




\subsection{Traditional philanthropy}

Traditional philanthropy (typified as foundation/responsive/reactive philanthropy) is the basis of modern philanthropy (Sealander, 1997). Fuelled by the nineteenth and earlytwentieth century expansion in charitable institutions and organizations, this conventional mode of philanthropy is largely engaged with ambitious economic and social reforms (Katz, 2005; Sealander, 1997). Despite its aspirations, many authors question the effectiveness of traditional philanthropy, claiming that it replicates various flaws of international aid. It is often uncritically described as beneficial, irrespective of its application (Bourguignon \& Sundberg, 2007; Burkemann, 2001) and, like international aid, has largely failed to promote sustainable local development and/or growth (Bourguignon \& Sundberg 2007; Desai \& Kharas, 2008; Doucouliagos \& Paldam, 2009).

Although without international aid to complement sovereign-state-led development, growth would have been slower in many countries (Collier, 2007), traditional philanthropy and international aid are grounded in Western understandings of development, which fail to take account of local histories and contexts (Sutcliffe, 1999). Thus, Korf (2007) argues that this form of assistance tends to marginalize local communities and turns the seemingly unconditional act of gift-giving into an asymmetrical relationship of powerful 'donors' and disempowered 'recipients'. This model also reinforces Western philanthropic paternalism and perpetuates 'mythological geographies' of development, whereby those in poverty are seen to require the assistance of the powerful (Ostrander, 2007; Simpson, 2004). Many of the problems we associate with aid (e.g. disorganized implementation, short-termism, over-ambitious projects, dependency, discouragement of self-help or local capacity-building, the flow of benefits 
to local elites and powerlessness to address the causes of poverty) can be attributed to the imperfect thinking of traditional philosophy (Bourguignon \& Sundberg, 2007; Nelson, 2008; Sundberg \& Gelb, 2006).

Clearly there are also many local factors that contribute to the failure of international aid, such as corrupt institutions and inadequate capacity-building. But, international aid has been justifiably critiqued for its: top-down approach; inability to stimulate grassroots structural change; lack of communication between donors and recipients; absence of accountability and evaluation and its historical association with export earnings, foreign policy agendas and in particular, security imperatives (Easterly, 2006; Nelson, 2008). Simply addressing the symptoms of poverty and underdevelopment, rather than proactively confronting their root causes, has turned traditional philanthropy into an unsustainable form of superficial charitable assistance, unable to deliver meaningful social change or to produce long-term results (Desai \& Kharas, 2008; Frumkin, 2000, 2006). Indeed, commentators question the motives of many modern philanthropists and argue that charitable gift-giving and volunteering has become a palliative for the Western liberal conscience and a way for individual and corporate philanthropists to 'buy' redemption in the form of psychological reward; that the 'feel good factor' and enhanced self-image associated with giving outweighs altruism (Bailin 2003; Bekkers \& Wiepking, 2011; Lyons \& Wearing, 2008; Mahrouse, 2011; Micklewright \& Schnepf, 2009; Micklewright \& Wright, 2005; Seglow, 2004).

\subsection{Modern Philanthropy}


Modern philanthropic approaches unfolded in the late-twentieth century when new ways to address global inequality emerged alongside the well-traversed traditional philanthropy practices. These approaches encompass three distinct forms: strategic-corporate, socialentrepreneurship and social-justice philanthropy (table 1). Strategic-corporate philanthropy is a form of corporate philanthropy, which developed from "the blending of traditional philanthropic values of social purpose with business approaches stressing direct engagement, innovation, problem-solving, efficiency, impact, measuring results, and leverage" (Plewes, 2008, p.8). Strongly connected with global corporate citizenship and corporate social responsibility, strategic-corporate philanthropy has been deployed to enhance organizations' competitive identities as well as for social engagement (Hero, 2001; McAlister \& Ferrell, 2002; Porter \& Kramer, 2002). It is widely defined as the "giving of corporate resources to address non-business community issues that also benefit the firm's strategic position" (Saiia, et al, 2003, p.170) as companies practicing it mobilize their enterprise-based capacities to achieve long-term social transformation (Brainard \& LaFleur, 2008). It has also been described as a form of 'philanthrocapitalism' (Edwards, 2009) or 'imperial benevolence' (Tiffin \& Gilbert, 2008), which concentrates wealth and power in the hands of businesses. For its critics, strategic-corporate philanthropy is, at best at odds with development goals for equality and empowerment and, at worst a form of '(neo-)colonial benevolence' lurking beneath a veneer of human welfare advocacy (Brantlinger, 2008).

Like strategic-corporate philanthropy, social-entrepreneurship philanthropy is a similar reaction to traditional philanthropy, with an increasing number of examples within the tourism sector (Tetzschner \& Herlau, 2003), including businesses, which 
donate a share of their profits, collect 'spare change' for good causes or send their staff on volunteering visits. Described as "a process by which citizens build or transform institutions to advance solutions to social problems" (Bornstein \& Davies, 2010, p.1), it has similarly attracted business-minded people determined to employ market-based mechanisms to achieve social change (De Lorenzo \& Shah, 2007; Reis \& Clohesy, 2001). However, these social entrepreneurs eschew traditional modes of accountability (where the return of initial capital investment serves as a key performance indictor) and focus on solving social problems by fostering sustainable social, political and economic opportunities (Wagner, 2002). This new form of philanthropy works toward addressing the social, economic and institutional infrastructure that encourages poverty and underdevelopment. Guided by donors who are more focused on long-term goals than short-term material or economic gains, this model is characterised by a highly collaborative hands-on approach, which sees small-scale entrepreneurial initiatives as the solution to lasting grassroots social transformation (Eikenberry, 2006; McCully, 2000).

Development and quality-of-life improvement are contingent upon adequate health care, education and sanitation and reduced levels of instability and conflict. Yet, in contemporary societies, poverty reduction, knowledge exchange and economic and social engagement cannot be achieved without access to income-generating opportunities, market economies, affordable goods, services and expertise and credit and saving institutions. Social-entrepreneurship philanthropy therefore places heavy emphasis on the ability of civil society partnerships to create sustainable social change (Bornstein \& Davies, 2010; Fraser, 2007; Perrini, 2006) and particularly champions the role of indigenous small- to medium-sized enterprises (SMEs) in addressing a lack of 
empowerment, participation and control in local communities (Dees, 2008; Prahalad 2010; Prahalad \& Hammond, 2002; Stern et al., 2005). Much of this work complements and expands small-grants programmes and microfinance ventures and seeks to stimulate public sector initiatives. As such, key characteristics of social-entrepreneurship philanthropy include: leveraging local resources for maximum impact; encouraging the private sector to invest in social issues; sharing technical skills amongst communities; forming networks of knowledge, expertise and technology; and promoting flexibility, monitoring, accountability and transparency.

Like other forms of philanthropy, social-entrepreneurship philanthropy has its detractors. It has been critiqued as a political tool, whose main purpose is appropriation and social control rather than sustainable social transformation; as an intervention that realigns but does not reset existing coordinates of power (Frumkin, 2006). Although there is agreement that proactive entrepreneurship plays a role in addressing underdevelopment and poverty, all too often disadvantaged communities' lack of a political voice and inadequate economic and social capacity prevent them from attracting business initiatives (Brown, 1998; Frumkin, 2000). An immediate challenge in social entrepreneurial strategy is identifying projects that will not waste the initial investment of capital, expertise and resources. The dilemma for social entrepreneurs is that a focus on the greatest need risks putting resources into "poorly managed, inefficient, and possibly ineffective environments" (Bourguignon \& Sundberg, 2007, p.320), whilst selecting "communities on which to focus can create disappointment and a sense of permanent exclusion within communities that are defined as ineligible for grants" (Frumkin, 2000, p.41). Indeed, without workable partnerships, enabling environments and a solid 
institutional framework, the potential of social enterprises may remain unrealised (Frumkin, 2000).

The final variant of modern philanthropy is social-justice or social-change philanthropy, a term used to describe "grant-making that aims to address the root causes of social and economic inequalities" (Goldberg, 2002, p.17). Largely preventive, this form of philanthropy has focused upon building a broad progressive movement, which enables marginalized and disenfranchised communities to challenge local power dynamics through political advocacy, activism, and policy/welfare initiatives (Goldberg, 2002). In this way, social-justice philanthropy is a form of giving that seeks lasting reform and societal transformation by tackling the conditions that make philanthropic intervention necessary in the first place (Dreier, 2002). In contrast to traditional 'direct service' philanthropic activities, which aim to improve the lives of others, but which seldom challenge long-standing societal issues, social-justice philanthropic funders "have gravitated toward a theory of leverage aimed at moving toward policy research and advocacy" (Frumkin, 2000, p.42). Integral to this model is the concept of 'idea/knowledge philanthropy', which hinges on innovation, creative planning and solution-making and community involvement - potentially representing an enhanced model for broad societal change (Frumkin, 2000).

\subsection{Post-modern Philanthropy}

The wider literature on travel philanthropy frames it as a form of post-modern philanthropy. This term post-modern "is very loaded and ambiguous term, [literally meaning] what comes 'after' and 'goes beyond' modernity, the cultural epoch in Western 
history characterised by a strong belief in the blessing of reason in science, moral philosophy, economics and politics" (Bruni \& Zamagni, 2013, p.345). Travel philanthropy indeed 'looks beyond', but also shares much in common with strategic, social-entrepreneurship and social-justice philanthropy as well as exhibiting characteristics of traditional philanthropy (table 1). Defined as: "the donating of money, in-kind resources (office equipment, flights, accommodation) or time (mentoring or volunteering), occasioned by or facilitated by travel" (Goodwin, et al, 2009, p.4), travel philanthropy is development assistance whereby funds, labour and/or other resources flow directly from the tourism industry into community development and environmental initiatives (Maathai, 2011). The giving can be either a core part of the tourism experience (i.e. volunteering, charitable tourism, conservation holidays) or it can be an incidental consequence of travelling in poverty-stricken locations (i.e. school fee sponsorship, donations to clinics and orphanages) or areas affected by major health and environmental problems (HIV or Ebola, desertification and loss of habitat, species in extinction, climate change, etc.). In either case, individual tourists and tourism business make “...concrete contributions of time, travel and treasure to local projects beyond what is generated through the normal tourism business" (Honey, 2011, p. 3).

Although not new, travel philanthropy has been accelerating as a concept and a movement, as a consequence of the democratization of charitable giving and the upsurge in international tourism to less developed economies (Desai \& Kharas, 2008; Mustonen, 2006; Nevarez, 2000; Valente \& Crane, 2010; Wearing, 2001). Tourism is a bridge between international and local communities and is uniquely positioned to promote philanthropy amongst those who perceive themselves as being more fortunate than others 
(Ashley \& Mitchell, 2007; Bornstein, 2009). Goodwin et al. (2009) suggest travel philanthropy as an umbrella term for three distinct practices: individual giving (either directly or via an intermediary such as a tour operator or a hotel business); corporate and/or personal charity fundraising; volunteering. In each case, agents of travel philanthropy devote their skills, professional expertise and/or financial resources to individual community projects and/or organizations to foster environmental stewardship, development solutions and sustainable social change (Goodwin et al., 2009; Honey, 2011). In this sense, travel philanthropy is promoted as part of broader geographies of care and responsibility, as a sustainable form of tourism ( $\operatorname{Sin}, 2010$ ), which combines acts of benevolence with a beneficial and socially just form of travel, in an effort to empower local communities, build capacity, preserve the natural environment and strengthen institutional collaboration and partnership (Honey, 2011; Maathai, 2011; Sin, 2010).

It has been suggested that travel philanthropy is most effective when it emulates social-entrepreneurship and social-justice philanthropy principles and adds value to extant sustainable and community-focused projects (Western, 2011). This notion speaks to ethical travel debates and the so-called 'moral turn' in tourism (Butcher, 2003; Caton, 2012; Smith \& Duffy, 2003), as well as debates in politics and sociology concerned with the rise of new forms of social activism (Beck, 2006; Tarrow, 2011). It hinges upon longterm development and extends community-based, pro-poor and eco-tourism approaches by magnifying their leverage (Brohman, 1996; Scheyvens, 2007). As "a new source of funding, administered locally for locally-defined priorities" (Honey, 2011, p. 9), it can complement and advance small-grants or microfinance business ventures, support government initiatives, improve access to material assets and leverage private sector 
resources (Honey, 2011). The main challenge for travel philanthropy is to capitalize on, yet differentiate itself from, traditional philanthropic approaches based on short-term, project-specific charitable donations, which tend to deliver fragmented results (Ashley \& Haysom, 2006). Travel philanthropy has made progress in this regard and is now seen by both donors and recipients as a unique 'trade-plus-aid' form of development assistance, whereby a travel philanthropist "can add far more than fees, standards, and fair trade practices" (Western, 2011, p.14).

As with other forms of philanthropy, travel philanthropy has its critics who locate it in neo-liberal ideologies of development since it associates pleasurable activities with charitable acts and commoditizes poverty and underdevelopment by subjecting them to the voyeuristic and patronizing gaze of tourists, who blur giving and volunteering with the pursuit of individuality and sociality (Azarya, 2004; Mustonen, 2007; Goodwin et al., 2009; Coghlan, 2011; Lyons, 2007; Lyons \& Wearing, 2008; Wearing et al, 2005). Travel philanthropy has also been described as: reinforcing unequal power relations between donors and recipients; generating cultural 'clashes'; destabilizing existing social systems; and instilling a sense of marginality and dependency in local communities (Abernethy, 2011; Korf, 2007; Sin, 2010). Indeed, philanthropic acts sometimes have unintended consequences or perpetuate the very structures they would challenge (Carnegie, 1993; Spalding, 2011). "Tourists like to contribute to what they see, particularly when visiting areas in need" (Ashley \& Haysom, 2006, p. 268) and they often react instantaneously, thinking that their actions can ameliorate suffering. The inadequacy of this traditional philanthropy becomes evident when travel philanthropy is: 
"more about impulse charity by travel[1]ers and/or contributions by tourism operators or hotels to meet what they perceive as local needs and priorities" (Coghlan, 2011, p.19).

Several travel philanthropy projects have failed to encourage critical dialogue between tourists and local communities, thereby leaving unchallenged Western essentialist assumptions and undermining some of the purported social benefits associated with the movement (Coghlan, 2011; Coghlan \& Fennell, 2009). Just like international aid and traditional philanthropy, travel philanthropy has frequently relied upon uncomplicated Western notions of development, which commonly reduce aid to a handful of simple projects, usually with no follow-up (Macy, 2011). Imposing such a topdown approach runs the risk of: unsustainable results; interrupted projects; dependency upon external and unpredictable giving; paternalistic attitudes; and unequal power relations (Easterly, 2006, 2007; Higgins-Desbiolles, (2006). As a consequence, many locals are often left disillusioned, with no capacity to take responsibility for their own development agenda and unable to exert control over the unsystematic actions of donors, which sometimes create more problems than solutions (Macy, 2011). For instance, whilst not directly relevant to our case study here, it is noteworthy that, in the context of travel philanthropy, volunteer tourism is increasingly criticised for ignoring local requirements, disrupting local economies, rationalising poverty, instigating unwanted cultural changes and reinforcing conceptualisations of the 'Other' (Guttentag, 2009).

\section{RESEARCH SETTING AND METHODS}

\subsection{The Research Setting}


The PBC was born out of a group of British tourists' desire to combine their thirst for adventure with support for West African local development initiatives. The PBC is the brainchild of Julian Nowill, a motor enthusiast who wanted to develop a more accessible alternative to the Paris-Dakar Race (where most of the participants benefit from corporate sponsorship). Julian and his colleagues launched what they termed the 'People's Challenge' from the UK city of Plymouth to the Gambian capital of Banjul, with three rules, namely that: no participating vehicle is to be worth more than US\$150; vehicle conversions for the 3,700 mile desert journey are limited to the value of US\$22; all rules are made to be broken. The rules capture the spirit of the event and are designed to enable as many people as possible to experience the adventure of driving through one of the world's last wildernesses.

The PBC later formed a partnership with the Association of Small Scale Enterprises in Tourism (ASSET), a trade association established in 2000 by a group of small and micro-independent businesses working collaboratively on product development, training, advocacy and quality development to diversify the Gambian tourism market and ultimately to alleviate local poverty (Carlisle et al, 2013). ASSET needed to raise a modest amount of money to support its operation and the PBC offered to donate funds raised from auctioning the participating vehicles that made it through the Sahara desert. Whilst just three teams originally pledged to make the journey from the UK on Boxing Day 2002, international media coverage boosted this figure to 36 teams, rising to 150 the year after. As the $\mathrm{PBC}$ evolved, a further partnership was formed between ASSET and the Gambia National Olympic Committee (GNOC), enabling the 
employment of a full-time member of staff to organise the car auctions and to undertake a thorough evaluation of how to employ the funds raised.

\subsection{Methodology}

In line with methodological approaches, which value the plurality of world views, cultural differences and research praxis (Pritchard et al, 2011), the paper is co-authored between an 'insider' (who lives in The Gambia) and three European 'outsiders' (see Beebe, 2001). The composition of the field research team by an 'insider' and an 'outsider with extensive research experience in the destination, thus created a high level of trust with local communities, gave unique access to key stakeholders and facilitated an equal exchange of ideas with the interviewees, who were recruited through the insider's local contacts and snowballing (see Novelli, Morgan \& Nibigira, 2012). The critical reflections on the evolution of the event since the first PBC (2002) by the insider were instrumental in identifying key historical milestones (table 2) and in critically considering the impacts of the event's philanthropic outputs. It is important to note, however, that these reflections were mediated and reviewed by her co-authors (i.e. through probing questions during the interviews), who had more 'distance' from the PBC as non-PBC-participants and UK-based academics.

Drawing upon evidence emerging from a longitudinal cohort study conducted in The Gambia between 2002-2011, this paper reports on fieldwork undertaken in informal settings using a retrospective analysis of personal diary entries and participant observations of the PBC events recorded daily between 2002-2011. Semi-structured interviews were undertaken between October and December 2011 to allow respondents to share their own $\mathrm{PBC}$ stories and enable data triangulation. While the personal diary 
entries and participant observations records kept by the 'insider' co-author, who is also part of the PBC's Steering Committee, served as framing and factual evidences from each PBC event during the period under investigation (e.g. issues faced by the PBC team associated with arrival of teams, challengers' behaviors and experiences, community expectations, organizational issues, auctions, etc.), this paper primarily discusses findings from interviews and informal conversations with a total of 27 respondents (organizers, PBC participants and aid beneficiaries).

The interviews were conducted, between October and December 2011, with six PBC organizers (coded $\mathrm{O} 1$ to O6), 13 PBC participants (coded P1 to P13) and eight funding beneficiaries (coded B1 to B8). The research participants included Gambians (12), British (11), Dutch (2) and German (2) respondents and were composed of 22 men and 5 women aged over 18 from varied social-economic levels and educational backgrounds. Four of the 13 participants had completed the PBC twice and engaged in other philanthropic initiatives. The interviews and informal conversations lasted between twenty minutes and one and half hour and were conducted in English, largely in the respondents' working environment or hotel in the case of the challengers. Although a set of predetermined questions had been identified, mainly aimed at determining the respondents' connection with the $\mathrm{PBC}$, we wanted our research partners to 'drive' the conversations and to provide insight into their experiences. We encouraged open conversation and tried to establish rapport, interactions which proved invaluable when analysing, interpreting and contextualizing the interview transcripts. To aid documentation, the respondents' permission was sought to tape-record interviews and make notes during the informal and casual conversations. Although most of respondents 
did not ask for anonymity, respondents are coded for consistency. The interviews were transcribed and analysed using qualitative content analysis, to 'identify core consistencies and meanings', which guided the identification of themes (Patton, 2002, p. 453). Content analysis was employed in the evaluation of the personal diary entries.

\section{THE PLYMOUTH-BANJUL CHALLENGE AND SUSTAINABLE DEVELOPMENT}

This section presents and analyzes the data collected through interviews and participant observations on the $\mathrm{PBC}$ and examines how it has evolved from its incidental beginnings rooted in traditional philanthropy into a travel philanthropy initiative, which is underpinned by social entrepreneurship and social justice philanthropy.

\subsection{Incidental Beginnings}

When all 36 PBC teams successfully completed the three-week journey from the UK to The Gambia in 2002, they had little awareness of the pitfalls of traditional philanthropy and, unsure what to do with their vehicles once their destination was reached, they decided to donate them to 'good causes'. However, as only government agencies and non-governmental organisations (NGOs) can drive right-hand-drive vehicles in The Gambia, some vehicles were incompetently converted to left-hand drive leaving them in a dangerous condition, whilst others were donated to spurious projects. One PBC participant tried to donate his old van to a 'needy' community: 
He returned a few days later saying that he had found a wonderful young health worker who he was going to donate his vehicle to, which was to become an ambulance for the village. All seemed very well, until the day of the auction where a ceremonial handover to the village was to take place. Unexpectedly, a group of elders from the village arrived protesting that the young man should not have the vehicle donated to him because his whole story was bogus. A bitter dispute erupted. (O1)

PBC participants' ignorance about local conditions and their desire for short-term 'good deeds' meant that they were in danger of doing "more harm than good" (Macy, 2011, p.177). No organization would have refused a vehicle; however, very few had the resources to maintain or fuel them and they were likely to end up abandoned on the roadside, with obvious enviromental implications. There were serious concerns about who should benefit from the PBC's charitable gift-giving and the ability of its recipients to develop sustainable outcomes; moreover the conflicts created at village level undermined some of the purported social benefits associated with the initiative and the organizations involved. Quite by chance, one of the following year's PBC drivers was in The Gambia on a fact-finding mission for the UK National Lottery, and was able to gain from the organizers some sense of how to better engage with local charities interested in receiving a donated vehicle. A dialogue with local agencies led to the development of a better focused and planned approach, which saw the vehicles auctioned to local projects instead of being directly donated to them, on the assumption that if they paid even a nominal sum for the vehicle, they would be far more motivated to maintain it. In addition, 
this auction raised US\$6,340, which was donated to ASSET and paid for its operational costs for the following year.

Table 2: PBC Development Timeline, 2002-2011

\begin{tabular}{|c|c|}
\hline Year & Milestone \\
\hline 2002 & First edition with 36 teams \\
\hline 2002 & Established partnership with ASSET \\
\hline 2002 & Established Steering Group \\
\hline 2003 & Established partnership with GNOC \\
\hline 2003 & PBC reaches peak of auction sales \\
\hline 2005 & PBC reaches peak of vehicles auctioned \\
\hline 2006 & Numbers of vehicles reaches all-time low \\
\hline 2010 & Established partnership with Camp Africa \\
\hline 2011 & Deteriorating political situation in Mali undermines initiative \\
\hline 2011 & Camp Africa as an alternative source of projects' funding \\
\hline 2011 & \\
\hline
\end{tabular}

\subsection{Strategic Progress}

The 2002 PBC organizers and participants left The Gambia doubting whether the 'adventure' would be repeated but, to their surprise, more than 150 teams registered for the 2003 edition, following extensive media coverage of the event. If their vehicles were auctioned for similar prices as in the previous year, then ASSET and GNOC would receive considerable funds, which required a plan to ensure these would be equitably distributed: 
A strategic plan was devised, whereby $40 \%$ of any monies raised would be used to meet the Challenge's administration costs; ASSET and GNOC would receive $20 \%$ each and the remaining $20 \%$ would be placed into the hands of a PBC Grant Allocation Committee, a group of respected Gambians who would follow the criteria set by the PBC Steering Committee. (O3)

The medium through which gift-giving would flow would be the vehicle auction; its impact would be measured by the performance of those benefitting from the funds; and the timeframes and over-arching goals would be determined by the the PBC Organizing Committee/ASSET/GNOC partnership, the last two with the knowledge of local needs and priorities. In line with the values of ASSET and GNOC, it was decided that any donations would directly support small-scale tourism enterprises and youth and sports development organizations. To guarantee that the money empowered local organizations and not those that could fund-raise overseas, the criteria also stated that beneficiaries must be Gambian-registered and Gambian-run. In a country where so many previous philanthropic projects had been directed by Western ideas, finally development decisions were to be made and implemented by Gambians themselves.

The PBC Steering Committee decided to limit the number of participating vehicles to 150 - all of which had to be left-hand-drive and then donated for auction. The only exceptions would be specialist vehicles (i.e. ambulances and fire engines) or participants' with pre-existing relationships with local organizations: 
With 150 teams participating for the second year, a new level of organization was required and a team of local volunteers was recruited along with a need to engage with the government at a higher level than had been previously necessary. (O2)

In 2003, a PBC Logistics Committee was established with representatives from Gambian Immigration and Customs, the Tourism Security Unit, The Gambian Police and The Gambian Ports Authority (table 2). This has since become a highly efficient operation ensuring "a warm welcome into the country, a different approach to the tough borders and check-points to which we were exposed en route" (P4).

\subsection{Impact of the $P B C$}

Between 2004 and 2011, the PBC raised around US\$850,000 through car auctions (table 3), supplemented by the sales of those deemed not roadworthy for spare parts or scrap metal. The funds supported in excess of 100 community, tourism, sports and youth projects (table 4) facilitated by ASSET and GNOC. At the micro-economic level, those that benefitted from funds raised by the PBC would have been unable to operate and/or fulfil their primary missions without it. Although the amount raised may appear insignificant compared to what mainstream tourism brings to The Gambia annually (attracting an average of 120,000 visitors per year contributing approximately $16 \%$ of national GDP), the extra 500 annual independent travellers associated with this event, which merges adventure and philanthropic travel, have made a significant contribution not only to each specific funded project, but also to word of mouth and media induced 
awareness about the destination, stimulating market diversification beyond its reputation as a mass 'winter sun' package tourism destination and spreading the benefits of tourism to its remote areas. For many PBC participants and community members, it has been a life-changing experience, reaching far beyond what mainstream tourism provides ( $\mathrm{P} 3, \mathrm{P} 4$, P7, P10). In fact, from a tourism development perspective, "several communities benefitted from the goodwill of its participants, which by engaging in this alternative form of travel, made an impact far beyond tourism". (B5)

ASSET's role as a partner of the PBC strengthened its power and ability to contribute to the country's social, economic and institutional landscape through a collaborative and hands-on approach (Eikenberry, 2006; McCully, 2000). Through its partnership with ASSET and GNOC, the PBC played a significant role in contributing towards the National aspiration of attracting lifestyle niche tourism travellers, beyond mass tourism and in assisting marginalized and disenfranchised communities by shifting the local tourism power dynamics from a Western desire for adventure into better focused advocacy, activism and policy/welfare initiatives, which are now core to its philanthropic and social entrepreneurship philosophy (Goldberg, 2002, Carlisle et al, 2013).

Table 3: PBC Vehicle Auction Sales, 2004-2011

\begin{tabular}{|c|c|c|}
\hline Year & Numbers of Vehicles & Auction Sales in Gambian Dalasi (GMD) \\
\hline 2004 & 53 & $1,800,000$ \\
\hline 2005 & 133 & $7,200,000$ \\
\hline 2006 & 148 & $6,925,955$ \\
\hline 2007 & 142 & $5,916,125$ \\
\hline 2008 & 74 & $2,773,381$ \\
\hline
\end{tabular}




\begin{tabular}{|c|c|c|}
\hline 2009 & 49 & $1,998,350$ \\
\hline 2010 & 11 & 411,759 \\
\hline 2011 & 15 & 654,770 \\
\hline Total & $\mathbf{6 2 5}$ & $\mathbf{2 7 , 6 8 0 , 3 4 0}$ \\
\hline
\end{tabular}


Table 4: PBC's Projects Supported, 2004-2009

\begin{tabular}{|c|c|}
\hline Core Area & Projects \\
\hline \multicolumn{2}{|r|}{2004} \\
\hline SMEs (7) & SMEs' seed funding (i.e. art, apiary); Solar power; Conference hall; Tourist bantaba; Volunteer placement. \\
\hline Sport (5) & Sports equipment; 2 sports pavilions; 8 lane track;. \\
\hline Education (4) & School sponsorship; stationary, garden tools, fencing, kitchen; construction of a school; SMEs' business skills training \\
\hline Community (4) & Voice of the young project; Kindergarden \& Village Development; school garden wall; multi-purpose playing court. \\
\hline \multicolumn{2}{|r|}{2005} \\
\hline SMEs (4) & Eco- tourism attractions; Skills centre development; Paper mill expansion; Eco-Lodge Construction. \\
\hline Sport (5) & Multi- purpose court; Sport facilities refurbishment; National Sports Centre library furniture and computers; Dressing Room. \\
\hline Education (5) & Technology Centre; School \& Skill Development refurbishing; College Sponsorship; Eco-tourism training; Sculptors' and Tye-dye workshops; \\
\hline Community (7) & Women’s Garden Project; Revolving fund for projects; Museum Fencing; Drip irrigation; 2 Pavilions; Multi-Purpose Centre. \\
\hline \multicolumn{2}{|r|}{2006} \\
\hline SMEs (5) & ASSET Information Centre; Generator; Honey Processing Station; Batik Capacity Building; KART Fund Administration. \\
\hline Sport (4) & Fencing of Village Football Field; Equipment for Gambia Sports Journalist Association; Mini Stadium Pavilion; Perimeter Fence. \\
\hline Education (7) & $\begin{array}{l}\text { Voice skill Development Project; Sponsorship for Responsible Tourism Course participants; upgrading of Gambia Hotel School; Home Economic } \\
\text { and Food Preservation Institution Development; Tourism for All training; National Library equipment; Computer Class and Office. }\end{array}$ \\
\hline Community (4) & Agri-programme; Craft Village Project; Skills Centre Office and Showroom; Multi Purpose Facilities. \\
\hline \multicolumn{2}{|r|}{2007} \\
\hline
\end{tabular}




\begin{tabular}{|c|c|}
\hline SMEs (5) & $\begin{array}{l}\text { Beekeeping; KART Administrative Support; SMEs' seed funding; Fruit Vendor and Juice Pressers' upgrading of facilities; Cultural Encounter's One } \\
\text { Year Rent And Salary. }\end{array}$ \\
\hline Sport (5) & Football Field Fencing; Administration Office; Sponsorships for Run 4 Health; \\
\hline Education (3) & Production of Audio-Visual Material; Scholarship for contribution towards MSc Responsible Tourism; Honey for Learning \\
\hline Community (5) & Tourism Security Unit; Promote Art; Art Centre fencing; Official Tourism Guide upgrading of Office; Women Project \\
\hline \multicolumn{2}{|r|}{2008} \\
\hline SMEs (4) & Seeding production nursery; Cultural Encounters’ product \& services; KART one year salaries for 2 staff; SMEs’ seed funding. \\
\hline Sport (1) & Renovating And Extension Basket Ball Court \\
\hline Education (3) & Tree Planting; Youth participation in enterprise development; Food Production. \\
\hline Community (3) & Human Rights Awareness; Construction of theatre; Future Ambassadors of Movie and Entertainment in Africa (FAME AFRICA) \\
\hline \multicolumn{2}{|r|}{2009} \\
\hline SMEs (3) & SMEs seed funding; Cultural Encounters' information centre; Upgrading of local pirogues \\
\hline Sport (2) & Food programme and basketball skill and sensitization on sexually transmitted disease; Supporting deaf people in the sports communities. \\
\hline Education (3) & Puppet making, traditional story telling and literacy; training material; Theatre for children and performing Artists in the Gambia \\
\hline Community (1) & Barra Community awareness, security and safety of the PBC Philanthropist, while awaiting the ferry to cross to Banjul. \\
\hline
\end{tabular}


In many instances, "the challengers themselves have contributed far more than $\mathrm{j}$ money, with many long-term local capacity-building spin-offs" (B7). For example:

Malcolm, a specialist in policy development working in the area of the deaf and hard-of-hearing, said that he would never have come to The Gambia, if it had not been the final destination of the Challenge. He was staggered by the warmth of the welcome and immediately knew that he would be back... he not only returned, but revisited The Gambia more than 20 times, each time bringing funds, equipment, skills and expertise to support services that were largely being run by untrained and underresourced personnel. He made connections with Sound Savers, which have not only provided a state-of-the-art mobile audiology unit, but also sent over a professional audiologist and technician for nine months to set the service up and train the Gambian members of staff, which are now running the unit. On one of his many visits, he and a number of colleagues from UK came during the school holidays and financed and ran a training course for staff from 25 up-country schools helping them to appreciate and spot potentially deaf children and to go on and work productively with them ensuring that they are properly assessed for their needs. (O3)

Similarly, two hospital technicians, having handed their vehicle over for auction, offer their services to the national hospital: 
They were horrified to find that all of the incubators were broken. Over the next few days they managed to get eight of the nine incubators working and then when they returned to UK negotiated with one of teams that was due to take part in the $\mathrm{PBC}$ in a later group to bring the part to fix the ninth. (O3)

\subsection{The Significance of the $P B C$}

There have been numerous problems associated the $\mathrm{PBC}$, ranging from:

$\ldots$ drivers who were not willing to enter into the spirit of the event and wanted to profiteer by selling their vehicles privately, to funds' beneficiaries who have not used the money wisely, to the local car dealers who formed a cartel at the auctions and the local bumsters targeting the Challenge drivers and their vehicles for their own gain by hassling or stealing equipment. (O4)

\footnotetext{
A further challenge was posed by one of the major international tour operators reducing the rates at their hotel at the time of the PBC, thereby undercutting small accommodation operators, and proving particularly detrimental to the hotel designated as the official 'finishing line'. Certainly, the PBC organizers have been confronted by an ever-changing environment, which has forced them to take ad hoc action in the absence of an initial plan. In terms of the philosophy of the event, this evolved from one based on individual
} 
participant gift-giving (traditional philanthropy) into a focused advocacy, activism and policy/welfare initiative guided by the PBC Steering Committee .

Although not without its challenges, the strategic partnerships with ASSET and GNOC were crucial to the PBC's successes. Without this collaboration, the PBC organisers and participants ran "the risk of putting resources in poorly managed, inefficient, and possibly ineffective environments" (Bourguignon \& Sundberg, 2007, p.320). Such mistakes were frequent in year one (2002), whilst in 2003 the PBC's monitoring processes were variable, only become effective in 2004. Changes from the early years included: ensuring that right-hand-drive vehicles were donated to government or non-governmental agencies, who did not have to convert them; selecting the most suitable community proposals; managing the expectations and reactions of communities ineligible for grant aid.

Since the early years, the PBC has improved its planning and management operations and collaborated closely with local authorities, which has made the event more efficient and addressed criticisms often levelled at social entrepreneurial philanthropy (Frumkin, 2000). It has spawned a number of copycat initiatives and in recent years similar challenges have arrived in The Gambia from Amsterdam, Dresden, St Petersburg, Dublin and Antwerp - each with varying degrees of philanthropic engagement and coherence. The Gambia is a small destination $\left(11,295 \mathrm{~km}^{2}\right.$ with a population of 1.7 million people) and the arrival of so many vehicles has had a detrimental effect on the prices they raise at auctions. The numbers of cars auctioned post-PBC is also on a downward trajectory as other adventures and destinations capture the public imagination. Moreover, further development of the $\mathrm{PBC}$ has been curtailed by international events 
beyond the organizers' control. Instability in countries on the PBC route, adverse travel advice on Mauritania and Mali and the Ebola outbreak in the region have all reduced the number of teams travelling through West Africa.

Given the previous successes attributed to the $\mathrm{PBC}$ and the falling number of entrants, the PBC Steering Committee is focussing on alternative fund-raising initiatives. It has used the $\mathrm{PBC}$ experience to diversify efforts and resources into a new initiative called Camp Africa (a locally registered charity), which follows 'global citizenship' principles facilitated through cross-cultural and sport activities and operates under the auspices of its trustees, ASSET and the International Centre for Responsible Tourism West Africa (Camp Africa, 2013). Thus, what began as an incidental union between an individual's desire for adventure and philanthropic engagements eventually evolved into a wider philanthropic movement based on a series of collaborations with local agencies, which impacted positively on a number of communities (table 4). It began in an ad hoc fashion and its successes are arguably the result of a somewhat fortuitous partnership with ASSET. Yet, by evolving from a traditional philanthropic model to one based on social-justice philanthropy, it ultimately made a positive contribution to sustainable community development initiatives.

\section{CONCLUSION}

This paper has presented critical reflections on the values, practices, benefits and shortcomings of traditional, modern and post-modern philanthropy in order to expand critical understandings of the broader concept of travel philanthropy. It has explored the evolution and impact of the specific case of the PBC, from an 'insider' and 'outsider' perspective, as illustrative of travel philanthropy practice to provide insights for both 
researchers and practitioners. This is not a study written completely by impartial observers, but there are clear advantages to a research team, which is privy to the internal discussions, dynamics and evolution of the Challenge.

Notwithstanding the complexity associated with travel philanthropy as an effective tool for community development and the challenging division between 'donors' and 'recipient of aid' experinced by both the challengers and the organising committee in the allocation of resources and funds, the paper led to some broader reflections on how in this case travel philanthropy eventually contributed to sustainable sovereign-state-led and community-led development initiatives, focused positive global media attention on a destination and promoted market diversification, adding niche tourism products to its 'winter/sun' offering.

In its first edition, the $\mathrm{PBC}$ showed clear connotations of traditional philanthropy practices leading to incidental, reactive, short-term, disorganized and supply-led undertakings, taking little cognizance of local community wishes, needs or imperatives. It was very possible that its story would have ended after its 2002 edition, but thanks to the intervention of a UK charity worker and $\mathrm{PBC}$ driver and wider public interest in the initiative, the resultant dialogue between its organizers and local agencies in The Gambia (notably ASSET) led to the assumption of more local control over the planning and management of the PBC itself. Thus, what had begun as a typical example of travel philanthropy rooted in Western notions of development aid and assistance evolved, although by no means seamlessly, into the PBC/ASSET/GNOC partnership, drawing upon social-justice or social-change philanthropy practices, generally aimed at addressing "the root causes of social and economic inequalities" (Goldberg, 2002, p.17) and 
enabling marginalized and disenfranchised communities to challenge local power dynamics through political advocacy, activism, and policy/welfare initiatives (Goldberg, 2002). The PBC/ASSET/GNOC partnership ensured that, in the PBC's later editions, local communities owned and exercised control over the decision making process, the identification of community needs, the fund allocation and defined and monitored the event's outcomes.

ASSET's role as the lead partner and main beneficiary of the PBC means that the philanthropic initiative has strengthened the country's social, economic and institutional landscape through a collaborative and hands-on approach (Eikenberry, 2006; McCully, 2000). This has been achieved by engaging recipients and paying attention to what Schervish (2007, p. 377) terms a long-term "social relation of care", which should be sought by philanthropists and individual donors striving to build a legacy of sustainable development. Through the facilitating role of ASSET and GNOC, the PBC has played a significant role in assisting marginalized and disenfranchised communities in The Gambia, raising around US\$850,000 to support over 100 development projects during 2002-2011. Whilst it began as a traditional philanthropic initiative, it has evolved into one very much aligned to social-entrepreneurship and social-justice-philanthropy and post-modern ways to 'look beyond' obvious ways to address local needs. It has indeed attempted to modify local tourism power dynamics through its advocacy work, activism, and policy/welfare initiatives. The community to which the PBC and similar initiatives, including Camp Africa, appeals is a restless one and it has already been drawn to other events and destinations, some of which have emulated the Challenge. The PBC peaked in 2005-2007 in terms of the numbers of participating teams, car auctions and funds raised 
and it has since been on a downward trajectory, a situation exacerbated by the deteriorating regional political situation and Ebola outbreak.

This brings us to two broad conclusions one can draw from this initiative. Firstly that travel philanthropy can be an unpredictable form of giving, which runs the risk of interrupted aid projects, with the $\mathrm{PBC}$ exemplifying this, despite its positive community development contributions. The second conclusion is that travel philanthropy projects, which are initiated either in close collaboration with local businesses or build upon existing community-driven tourism initiatives and experiences, can lead to more sustainable, integrated 'destination-wide travel philanthropy' engagements. Well-crafted travel philanthropy initiatives need to take into account a number of factors/pitfalls in order to deliver long-term, predictable benefits to local community projects and, for its many flaws, travel philanthropy has provided simple solutions to specific microdevelopment challenges. The lessons learnt from the $\mathrm{PBC}$ have created a better understanding of the need for more strategic thinking in terms of how other initiatives (e.g. Camp Africa) are run and for greater clarity around their aspirations and the sustainability of their outcomes.

Travel philanthropy initiatives like the PBC are diverse and, whilst each one is unique, making comparison difficult, there are a myriad of travel philanthropy engagements growing out of individual initiatives, which share the same characteristic. They all go beyond the typical model of travel philanthropy born out of a tourism business or group of businesses in one destination raising funds (and/or material donations or volunteers) from their own customers or clients. The extant tourism literature is largely focused on this typical model of travel philanthropy, and although it is 
unwise to extrapolate too many wider lessons about the effectiveness of travel philanthropy from the PBC, it does exemplify how an initiative can evolve across all three philanthropic approaches and culminate as social-justice travel philanthropy. Whilst it clearly carries this caveat, the paper has made a contribution to the unfolding critical literature and current debates on the morality and efficacy of charity and philanthropy in general and travel philanthropy in particular. There remains much to do in this area and future research could develop its findings along two dimensions of the travel philanthropy debate, which might be termed 'ethical' and 'political' dimensions. The first concerns what we do as individuals, consumers and travellers; the second addresses the role of philanthropy and travel philanthropy as a social and political construct. The complex and multiple interconnections between the two are subject to continuous contest and challenge and offer fertile ground for further study.

\section{REFERENCES}

Abernethy, D. (2011). Unintended Consequences of the Traveler's Best Intentions. In M Honey (Ed.) Travelers' Philanthropy Handbook (pp. 179-190) Washington: Center for Responsible Travel,

Adam, T. (2004). Introduction. In T. Adam (Ed.) Philanthropy, Patronage, and Civil Society: Experiences from Germany, Great Britain and North America (pp. 1-10) Bloomington, Indiana: Indiana University Press. 
Ashley, C. \& Haysom, G. (2006). From Philanthropy to a Different Way of Doing Business: Strategies and Challenges in Integrating Pro-poor Approaches into Tourism Business. Development Southern Africa 23(2) 265-280.

Ashley, C. \& Mitchell, J. (2007). Assessing How Tourism Revenues Reach the Poor Briefing Paper 21, London: ODI.

Azarya, V. (2004). Globalization and International Tourism in Developing Countries: Marginality as a Commercial Commodity. Current Sociology, 52(6), 949-967.

Bailin, M.A. (2003). Requestioning, Reimagining, and Retooling Philanthropy. Nonprofit and Voluntary Sector Quarterly 32(4) 635-642.

Bekkers, R. \& Wiepking, P. (2011). A Literature Review of Empirical Studies of Philanthropy: Eight Mechanisms that Drive Charitable Giving. Nonprofit and Voluntary Sector Quarterly 40(5) 924-973.

Beck, U. (2005). Power in the Global Age. Cambridge: Polity.

Bornstein, D. \& Davis, S (2010). Social Entrepreneurship: What Everyone Needs to Know. Oxford: Oxford University Press.

Bornstein, E. (2009) The Impulse of Philanthropy. Cultural Anthropology 24(4) 622-651. 
Bourguignon, F. \& Sundberg, M. (2007) Aid Effectiveness: Opening the Black Box. The American Economic Review 97(2) 316-321.

Brainard, L. \& LaFleur, V. (2008). Making Poverty History? How Activists, Philanthropists, and the Public are Changing Global Development?. In H. Gilbert \& C. Tiffin (Eds.) Burden or Benefit? Imperial Benevolence and its Legacies (pp. 13-28) Bloomington: Indiana University Press.

Brendon, P. (1991) Thomas Cook: 150 Years of Popular Tourism. London: Secker \& Warburg.

Brohman, J. (1996) New Directions in Tourism for the Third World. Annals of Tourism Research, 23(1) 48-70.

Brown, D.R. (1998). Evaluating Institutional Sustainability in Development Programmes: Beyond Dollars and Cents. Journal of International Development, 10(1) 55-69.

Bruni, L. \& Zamagni, S. (2013) Handbook on the Economics of Reciprocity and Social Enterprise, Cheltenam: Edward Elgar Publishing.

Burkemann, S. (2001). An Unsatisfactory Company. Development Update, 3(4) 151-166. 
Butcher, J. (2003). The Moralisation of Tourism: Sun, Sand...Saving the World?. London: Routledge.

Butcher, J. \& Smith, P. Volunteer Tourism: The lifestyle politics of international development London: Routledge

Camp Africa (2013). About Camp Africa. Retrieved 18 February 2013 from http://campafricagambia.org/About_Camp_Africa.html

Carlisle, S., Kunc, M., Jones, E. \& Tiffin, S (2013). Supporting innovation for tourism development through multi-stakeholder approaches. Tourism Management, 35, 59-69.

Carnegie, A. (1993). The Gospel of Wealth. Indianapolis: Indiana University Center On Philanthropy.

Caton, K. (2012). Taking the Moral Turn in Tourism Studies. Annals of Tourism Research, 4, 1906-1928.

Coghlan, A. (2011). Adventure Philanthropy: Trailing a New Blend of Tourism and Volunteering. In M.J. Gross (Ed.) CAUTHE 2011 National Conference: Tourism Creating a Brilliant Blend. Adelaide, S.A.: University of South Australia.

Coghlan, A. \& Fennell, D. (2009). Myth or Substance: An Examination of Altruism as the Basis of Volunteer Tourism. Annals of Leisure Research, 12(3/4), 377-402. 
Collier, P. (2007). The Bottom Billion: Why the Poorest Countries Are Failing and What Can Be Done About It?. Oxford: Oxford University Press.

De Lorenzo, M. \& Shah, A. (2007). Entrepreneurial Philanthropy in the Developing World: A New Face for America, a Challenge to Foreign Aid. Washington: American Enterprise Institute for Public Policy Research Retrieved 23 ${ }^{\text {rd }}$ March 2014 from: http://www.sevenfund.org/pdf/Entreppreneurial\%20Philanthropy\%20in\%20the\%20Devel oping\%20World.pdf.

Dees, J.G. (2008). Philanthropy and Enterprise: Harnessing the Power of Business and Entrepreneurship for Social Change. In L. Brainard \& D.H. Chollet (Eds.) Global Development 2.0: Can Philanthropists, the Public, and the Poor Make Poverty History? (pp 120-134) Washington: The Brookings Institution.

De La Mare, T. (2014). Footloose Philanthropy. CampdenFO. Summer 2014, 46-51.

Desai, R.M. \& Kharas H. (2008). The California Consensus: Can Private Aid End Global Poverty?. Survival 50(4) 155-168.

Doucouliagos, H \& Paldam, M. (2009). The Aid Effectiveness Literature: The Sad Results of 40 Years of Research. Journal of Economic Surveys, 23(3) 433-461. 
Dreier, P. (2002). Social Justice Philanthropy: Can We Get More Bang for the Buck?. Social Policy, 33(1), 27-33,

Easterly, W. (2006). The White Man's Burden: Why the West's Efforts to Aid the Rest Have Done So Much Ill and So Little Good. New York: Penguin Books.

Easterly, W. (2007). Was Development Assistance a Mistake?, The American Economic Review 97(2) 328-332.

Edwards, M. (2009) Why 'Philanthrocapitalism' Is Not the Answer: Private Initiatives and International Development. In M.K. van Lieshout \& R. Went (Eds.) Doing Good or Doing Better: Development Policies in a Globalizing World (pp. 237-254) The Hague: Scientific Council for Government Policy WRR.

Eikenberry, A.M. (2006) Giving Circles: Growing Grassroots Philanthropy. Nonprofit and Voluntary Sector Quarterly, 35(3) 517-532.

Frumkin, P. (2000). Philanthropic Leverage. Society, 37(6) 40-46.

Frumkin, P. (2006). Strategic Giving: The Art and Science of Philanthropy. Chicago, IL: The University of Chicago Press. 
Goldberg, A.D. (2002). Social Change Philanthropy and How It's Done. Foundation News and Commentary, 43(3) 17-20.

Goodwin, H., McCombes, L. \& Eckardt, C. (2009). Advances in Travel Philanthropy: Raising Money through the Travel and Tourism Industry for Charitable Purposes. London: WTM Report.

Guttentag, D.A. (2009). The possible negative impact of volunteer tourism. International Journal of Tourism Research, 11(6) 537-551.

Handy, C. (2007). The New Philanthropists. The New Generosity. London: William Heinemann.

Hero, P.D. (2001). Giving Back the Silicon Valley Way: Emerging Patterns of a New Philanthropy, New Directions for Philanthropic Fundraising, 32, 47-58.

Higgins-Desbiolles, F. (2008) 'Justice tourism and globalisation', Journal of Sustainable Tourism, 16(3): 345-364.

Higgins-Desbiolles, F. (2006) 'More than an "industry": The forgotten power of tourism as a social force', Tourism Management, 27(6) 1192-1208 
Honey, M. (2011). Origin and Overview of Travelers' Philanthropy. In M. Honey (Ed.) Travelers' Philanthropy Handbook (pp. 3-12) Washington: Center for Responsible Travel.

Katz, S.N. (2005). What Does It Mean to Say that Philanthropy is "Effective"? The Philanthropists' New Clothes. Proceedings of the American Philosophical Society, 149(2), 123-131.

Kharas, H. (2008) The New Reality of Aid. In L. Brainard \& D.H. Chollet (Eds.) Global Development 2.0: Can Philanthropists, the Public, and the Poor Make Poverty History? (pp. 53-73) Washington: The Brookings Institution.

Korf, B. (2007). Antinomies of Giving: Moral Geographies and Post-Tsunami Aid in Southeast Asia. Geoforum, 38(4) 366-378.

Lyons, K. (2007). Innovations In Volunteer Tourism: A Case Study Of Fundraising Adventure Tours. BEST Education Network Think Tank VII - Innovations for Sustainable Tourism. Northern Arizona State University.

Lyons, K. \& Wearing, S. (2008) All for a Good Cause? The Blurred Boundaries of Volunteering and Tourism. In K. Lyons \& S. Wearing (Eds.) Journeys of Discovery in Volunteer Tourism (pp. 147-154) Wallingford, UK: CABI International. 
Maathai, W. (2011) Foreword. In M. Honey (Ed.) Travelers' Philanthropy Handbook. (pp. 1-2) Washington: Center for Responsible Travel.

Macy, P. (2011) Unwanted Philanthropy: The Paint Syndrome. In M. Honey (Ed.) Travelers' Philanthropy Handbook. (pp. 177-178) Washington: Center for Responsible Travel.

Mahrouse, G. (2011) Feel-good tourism: An Ethical Option for Socially-Conscious Westerners?. ACME: An International E-Journal for Critical Geographies, 10(3), 372391.

McAlister, D.T. \& Ferrell, L. (2002) The Role of Strategic Philanthropy in Marketing Strategy. European Journal of Marketing, 36(5/6), 689-705.

McCully, G. (2000). Is This a Paradigm Shift?. Foundation News and Commentary, 4l(2), 20-22.

McGehee, N.G. (2014). Volunteer tourism: evolution, issues and futures. Journal of Sustainable Tourism, 22(6), 847-854.

Micklewright, J. \& Schnepf, S.V. (2009). Who Gives Charitable Donations for Overseas Development?. Journal of Social Policy, 38(2), 317-342. 
Micklewright, J. \& Wright, A. (2005). Private Donations for International Development. In A. B. Atkinson (Ed.) New Sources of Development Finance. (pp. 90-117). Oxford: Oxford University Press.

Monroe, K.R. (1996). The Heart of Altruism: Perceptions of a Common Humanity. Princeton: Princeton University Press.

Mostafanezhad, M. (2013). The Geography of Compassion in Volunteer Tourism. Tourism Geographies: An International Journal of Tourism Space, Place and Environment. 15 (2), 318-337.

Mustonen, P. (2006). Volunteer Tourism: Postmodern Pilgrimage?. Journal of Tourism and Cultural Change, 3(3), 166-170.

Mustonen, P. (2007). Volunteer Tourism - Altruism or Mere Tourism?. Anatolia: Journal of Tourism and Hospitality Research, 18(1), 97-115.

Nelson, J. (2008). Effecting Change through Accountable Channels. In L. Brainard \& D.H. Chollet (Eds.) Global Development 2.0: Can Philanthropists, the Public, and the Poor Make Poverty History?. (pp. 149-186) Washington: The Brookings Institution. 
Nevarez, L. (2000). Corporate Philanthropy in the New Urban Economy: The Role of Business-Nonprofit Realignment in Regime Politics. Urban Affairs Review, 36(2), 197227.

Novelli, M., Morgan, N. \& Nibigira, C. (2012). Tourism in a Post-Conflict Situation of Fragility, Annals of Tourism Research. 39 (3), 1446-1469.

Ostrander, S. (2007). The Growth of Donor Control: Revisiting the Social Relations of Philanthropy. Nonprofit and Voluntary Sector Quarterly. 36(2), 356-372.

Patton, M. Q. (2002). Qualitative research and evaluation methods London: Sage.

Payton, R.L. (1988). Philanthropy: Voluntary Action for the Public Good. New York: Macmillan.

Plewes, B. (2008). Global Philanthropy and International Cooperation: A Guide to Trends and Issues. Retrieved 20 $0^{\text {th }}$ March 2014 from: http://dspace.cigilibrary.org/jspui/bitstream/123456789/26891/1/Global\%20Philanthropy \%20and\%20International\%20Cooperation.pdf?1.

Porter, M.E. \& Kramer, M.R. (2002). The Competitive Advantage of Corporate Philanthropy. Harvard Business Review. 80(12), 56-68. 
Prahalad, C.K. (2010). The Fortune at the Bottom of the Pyramid: Eradicating Poverty through Profits. Upper Saddle River, NJ: Wharton School Publishing.

Prahalad, C.K. \& Hammond A. (2002). Serving the World's Poor, Profitably. Harvard Business Review, 80(9), 48-57.

Pritchard, A., Morgan, N. \& Ateljevic, I. (2011). Hopeful tourism: A new transformative perspective. Annals of Tourism Research, 38(3), 941-963.

Reis, T.K. \& Clohesy S.J. (2001). Unleashing New Resources and Entrepreneurship for the Common Good: A Philanthropic Renaissance. New Directions for Philanthropic Fundraising, 32(Summer), 109-144,

Saiia, D.H., Carroll, A.B. \& Buchholtz A.K. (2003). Philanthropy as Strategy: When Corporate Charity 'Begins at Home'. Business and Society 42(2), 169-201.

Salamon, L.M. (1992). America's Nonprofit Sector: a Primer. New York: Foundation Center.

Schervish, P.G. (2007). Is Today's Philanthropy Failing Beneficiaries? Always a Risk, but Not for the Most Part. Nonprofit and Voluntary Sector Quarterly, 36(2), 373-379. 
Scheyvens, R. (2007). Exploring the Tourism-Poverty Nexus. Current Issues in Tourism $10(2 / 3), 231-254$.

Sealander, J. (1997). Private Wealth \& Public Life: Foundation Philanthropy and the Reshaping of American Social Policy from the Progressive Era to the New Deal. Baltimore, Maryland: The John Hopkins University Press.

Seglow, J. (2004). The Ethics of Altruism: Introduction. In J. Seglow (Ed.) The Ethics of Altruism. (pp. 1-8). London: Frank Class Publishers.

Simpson, K. (2004). 'Doing Development': The Gap Year, Volunteer Tourists and a Popular Practice of Development. Journal of International Development, 16(5), 681-692.

Sin, H.L. (2010). Who are we responsible to? Locals' tales of volunteer tourism. Geoforum, 41(6), 983-992.

Smith, M. \& Duffy, R. (2003). The Ethics of Tourism Developmen London: Routledge.

Spalding, M.J. (2011). What is Successful Philanthropy?. In M. Honey (Ed.) Travelers' Philanthropy Handbook. (pp 19-24). Washington: Center for Responsible Travel.

Stephenson, M. (2014). Deciphering 'Islamic hospitality': Developments, challenges and opportunities. Tourism Management, 40, 155-164. 
Sulek, M. (2010a). On the Modern Meaning of Philanthropy. Nonprofit and Voluntary Sector Quarterly, 39(2), 193-212.

Sulek, M. (2010b). On the Classical Meaning of Philanthrôpia. Nonprofit and Voluntary Sector Quarterly. 39(3), 385-408.

Sundberg, M. \& Gelb, A. (2006). Making Aid Work. Finance and Development, 43(4), 1-10.

Sutcliffe, B. (1999). The Place of Development in Theories of Imperialism and Globalization. In R. Munck \& D. O’Hearn (Eds.) Critical Development Theory: Contributions to a New Paradigm (pp. 135-154) London: Zed Books.

Tetzschner, H. \& Herlau, H. (2003). Innovation and social entrepreneurship in tourism A potential for local business development? Retrieved 18 February 2013 from http://static.sdu.dk/mediafiles/Files/Om_SDU/Institutter/Miljo/ime/wp/tetzschner49.pdf .

Tiffin, C. \& Gilbert, H. (2008). Introduction: What's Wrong with Benevolence?. In H. Gilbert, C. Tiffin (Eds.) Burden or Benefit? Imperial Benevolence and Its Legacies (pp 1-12) Bloomington, IN: Indiana U.P..

Turner, S.G. (2011) Power in Movement. Cambridge: University Press. 
Valente, M. \& Crane, A. (2010). Public Responsibility and Private Enterprise in Developing Countries. California Management Review, 52(3), 52-78.

Wagner, L. (2002). The 'New' Donor: Creation or Evolution?. International Journal of Nonprofit and Voluntary Sector Marketing, 7(4), 342-353.

Wearing, S. (2001). Volunteer Tourism: Experiences that Make a Difference. Wallingford, UK: CABI.

Western, D.J. (2011). Travelers' Philanthropy and the Good Samaritan. In M. Honey (Ed.) Travelers' Philanthropy Handbook (pp. 13-18) Washington: Center for Responsible Travel.

Wolpert, J. (2002) The Distributional Impacts of Nonprofits and Philanthropy. In P. Flynn \& V.A. Hodgkinson (Eds.) Measuring the Impact of the Nonprofit Sector (pp. 123136) New York: Kluwer Academic/Plenum Publishers 